\title{
RADIOCARBON DATING OF CERAMIC MATERIALS: PROGRESS AND PROSPECTS
}

\author{
SUZANNE P DE ATLEY* \\ Department of Anthropology and Institute of Geophysics, \\ University of California, Los Angeles
}

\begin{abstract}
Although initial studies in the 1960's established the feasibility of applying the radiocarbon technique directly to ceramics, subsequent analyses have revealed this category of materials to be more complex than previously believed. Consideration of the points at which various types of organic carbon are introduced into ceramic materials by natural or human agencies allows more effective screening of potential sherd samples. It also suggest ways to overcome some of the limiting factors involved in dating ceramics.
\end{abstract}

\section{INTRODUCTION}

The paucity of charcoal or other readily datable material in many archaeologic sites often confounds the archaeologist's attempts to obtain absolute dates for his studies. In addition, even in cases where datable material can be found, its association with the cultural activity of interest is often suspect. This situation has prompted several researchers to turn their attention to other types of materials, such as ceramic artifacts. The advantages of such material are several. First, it provides direct dates on cultural material. Second, the association of dated material with the primary depositional context or the cultural activity of interest can be more readily evaluated. Third, ceramic materials, particularly utilitarian wares, are usually preserved in the form of sherds in many archaeological contexts, and are often expendable in quantities sufficient to produce a reliable radiocarbon date.

\section{Initial experiments}

Initial studies in the 1960's established the feasibility of applying the radiocarbon technique directly to ceramic materials. The operating assumption is that organic material present in the sherds represents only cultural activity, and that it was introduced in two ways: 1) organic tempering material might be added to the clay during the manufacture of the vessel, and 2) soot and food residue might be deposited in coarse wares during the use of the vessel. The method generally used to obtain a date involves crushing several kilograms of sherds to a fine size and treating them with hydrochloric acid to remove inorganic carbon. The residue is then burned and purified for $\mathrm{CO}_{2}$ counting.

The first attempts utilized sherds tempered with various organic materials such as carbonized bark and charcoal (Ralph, 1959; Evans and Meggers, 1962; Stuckenrath, 1963). Of those samples that could be related to known cultures and/or associated dated material, only the sherds with extremely small amounts of organic carbon $(<.6$ percent) produced questionable dates. However, the use of organic tempering is not prevalent everywhere, and even when it is used, the organic material often burns away completely in firing. Consequently, later studies were undertaken

* Present address: Conservation Analytical Laboratory, HTB AB070, Smithsonian Institution, Washington, DC, 20009 
to test the validity of ${ }^{14} \mathrm{C}$ determinations based on finely dispersed organic material in low-fired ceramics due to soot from cooking fires or to other organic matter not burned out of the clay during firing (Engstrand, 1965; Taylor and Berger, 1968; Taylor, Swain, and Berger, 1968). The correspondence between ${ }^{14} \mathrm{C}$ dates on ceramics and other independently dated associated material was very good, and investigators were able to conclude that ceramic materials could be reliably dated if ordinary precautions were exercised in selecting and pretreating sherds. The major drawback was the small organic carbon content of most sherds and the need to process large quantities of material.

Subsequent analyses performed on ceramics from the Pacific and southwestern United States revealed them to be a more complex category of materials than previously believed. Correspondence of sherd dates and associated archaeologic dates was the exception rather than the rule.

An extensive series of sherds from Palau in the Philippine Islands was submitted to the UCLA laboratory by Douglas Osborne, along with a set of charcoal samples. Although these were not paired samples, they were expected to date events which could be placed relatively within the same temporal framework. The sherd dates were evaluated by cross-dating and stratigraphy, and by extrapolation from the charcoal dates (see table 1). While the charcoal dates fell within the expected range, the sherd samples were all far too old (Osborne, in press). The temporal range for the charcoal samples was from $285 \pm 80$ (UCLA-1762K) to $1800 \pm 80$ years BP (UCLA-1762I), while the sherd dates ranged between $3320 \pm 80$ (UCLA-1855H) to $8150 \pm 80$ years BP (UCLA-1855FF). This is a rather significant discrepancy for materials from the same cultural horizons.

The southwestern United States material was less consistent in terms of the results obtained (see table 2). As with the Palau sherds, the dates were based on the finely dispersed organic material present in the ceramics. While three sherd dates corresponded with the associated treering dates and pottery seriations, the rest ranged from older than expected to more recent than expected, and even dated to $>100$ percent modern, indicating the incorporation of bomb carbon. This lack of consistency in the direction of error in the dates suggested that carbon from non-cultural sources may also be present in ceramic materials, and it may effectively dilute the age or otherwise contaminate the cultural sample.

Consideration of the steps involved in the manufacture and use of pottery can help to delimit the points at which non-cultural carbon of varying age may be incorporated into the ceramic material, and thereby, account for the discrepancies as well as the acceptable dates obtained. Knowing the sources of this carbon and the points at which it is introduced should facilitate more effective screening of potential sherd samples. It should also suggest ways to overcome some of the limiting factors involved in dating.

Sources of carbon in ceramic materials

A survey of ethnographic and ethnohistoric studies on primitive ceramic technology indicates that there are four points at which organic 
carbon can be introduced that may not represent the time of manufacture or use of a vessel. Briefly, these are in the selection of clay, the selection of temper, the use of the vessel during its "lifetime", and in the post-use or depositional environment. Each of these points will be examined for their effect on the apparent age of the pottery.

\section{Clay}

Primitive potters use a wide range of clays, including many impure, low-grade varieties with high organic matter content. Some of these highly carbonaceous clays require long oxidation periods in firing, and fairly high temperatures to burn out the organic material. Consequently, oxidation is not complete in many low-fired wares, and a "carbon core" remains, bearing the finely dispersed organic matter in the clay source. Since the types of clays used by prehistoric potters vary geologically from recently formed to older shale deposits that are ground for use, the inherent age of the organic material in the carbon core may affect the age of the ceramics. Furthermore, the effect may vary according to the extent of the core throughout the ceramic body; vagaries in firing may result in sets of vessels which have been oxidized to different degrees.

Residual or primary clays in contact with igneous rock from which they are formed usually have the fewest organic impurities. Nonetheless, such clays are variable in this respect. In surface clays of recent origin, the organics may be decaying vegetal matter (Shepard, 1965; Lawrence, 1972). Although larger materials, such as leaves, would probably be picked out and discarded by the potter, finely divided humus from disintegration of root systems would remain (Eyre, 1968). Because these materials are roughly contemporaneous with the selection of clay and subsequent manufacture of the pot, it is unlikely that their presence in a carbon core would be problematic.

On the other hand, sedimentary clays may be extremely high in organics. The amount varies from about 1 percent in glacial and alluvial clays to about 10 percent in shales (Shepard, 1965; Lawrence, 1972). Since these clays have been transported and redeposited, along with many different types of impurities, the source and age of the constituent organics is highly suspect. Clays derived from shale deposits contain peat, lignite, and various forms of coal that would significantly "dilute" the age of the ceramics, making them seem older than expected. In this case, it is necessary to assess the range of clay sources potentially available to prehistoric potters and obtain samples to use as correction factors.

Some of the anomalous dates in tables 1 and 2 can be explained to some extent by this factor. In the southwestern series, UCLA-1931A comes from an area in northern Arizona where the clays used in ceramic manufacture are derived from shales (Hack, 1942). The Palau samples are also made of clay with older organic materials. Two types of environments, volcanic and limestone islands (Osborne, 1966) are represented by these samples. Although there is no assurance that only one clay source was used, the clay is probably entirely from the volcanic islands 
(Osborne, in press; Hidikata, 1973). Osborne provided a raw clay sample from Palau, UCLA-1906, which gave a date of $1890 \pm 400$ years. When this date was used as a rough correction factor for the sherd dates, UCLA-1855H, J, K, S, and BB fell much closer to the expected dates. The lack of correspondence by the other samples may indicate the use of a different clay source. This should be more systematically examined.

\section{Temper}

As a category of material, organic tempers are the most suitable for dating because they usually consist of straw, grasses, ash, or other materials whose apparent age is contemporaneous with the manufacture of the pottery. However, fresh-water and marine shells have also been used in prehistoric pottery, but these would not necessarily represent the time of manufacture. In addition to the question of initial ${ }^{14} \mathrm{C}$ content of the shells, such carbonate tempers may be susceptible to $\mathrm{CO}_{2}$ substitution

TABLE 1

Palau ceramic dates

\begin{tabular}{|c|c|c|c|}
\hline Lab no. & Sample description & Date $\mathbf{B P}$ & Associated date* \\
\hline UCLA-1855H & $\begin{array}{c}\text { Aulong, Au 1, Wall } \\
\text { test St II, level } 3 . \\
0.43 \% \text { organic C }\end{array}$ & $3320 \pm 80$ & $\begin{array}{l}\text { Au } 1 \text { is a reef (limestone) } \\
\text { island. Date should be UCLA- } \\
\text { 1762E (charcoal): } 1480 \pm 80\end{array}$ \\
\hline UCLA-1855I & $\begin{array}{l}\text { Aulong, Au 1, Wall } \\
\text { test, St III, level 4, } 5 \text {. } \\
1.10 \% \text { organic C }\end{array}$ & $6530 \pm 80$ & $\begin{array}{l}\text { Expect slightly older than } \\
\text { UCLA-1762E }\end{array}$ \\
\hline UCLA-1855J & $\begin{array}{l}\text { Aulong, Au 1, Wall } \\
\text { test St IV, level } 6,7,8 . \\
0.99 \% \text { organic C }\end{array}$ & $4970 \pm 80$ & $\begin{array}{l}\text { Should be oldest of the } 3 \\
\text { samples. Older than expected, } \\
\text { but may be OK }\end{array}$ \\
\hline UCLA-1855K & $\begin{array}{l}\text { Aulong, Au l, F-E } \\
\text { test, bottom, level } 7,8 . \\
0.98 \% \text { organic C }\end{array}$ & $3780 \pm 80$ & Older than expected \\
\hline UCLA-1855Q & $\begin{array}{l}\text { Babeldaob, B } 37 \text {, } \\
\text { Coconut Grove test St II, } \\
\text { level } 3.0 .70 \% \text { organic C }\end{array}$ & $4475 \pm 80$ & $\begin{array}{l}\text { Volcanic island, coastal site, } \\
\text { UCLA-1762G (B37 Coconut } \\
\text { Grove St II, levels 12-36", } \\
\text { charcoal): } 1055 \pm 80\end{array}$ \\
\hline UCLA-1855S & $\begin{array}{l}\text { Babeldaob, B 37, } \\
\text { North Face test, level } 2 . \\
0.64 \% \text { organic C }\end{array}$ & $3800 \pm 80$ & $\begin{array}{l}\text { Volcanic terrace site. Should } \\
\text { date in same range as UCLA- } \\
\text { 1762E: } 1480 \pm 80\end{array}$ \\
\hline UCLA-1855X & $\begin{array}{l}\text { Babeldaob, B } 19 \text {, } \\
\text { level } 2,3 \text {. } \\
1.03 \% \text { organic C }\end{array}$ & $7610 \pm 80$ & $\begin{array}{l}\text { Volcanic; ca } 6500 \text { years too } \\
\text { old }\end{array}$ \\
\hline UCLA-1855BB & $\begin{array}{l}\text { Babeldaob, B } 18, \\
\text { Altar test St I. } \\
1.01 \% \text { organic C }\end{array}$ & $3760 \pm 80$ & $\begin{array}{l}\text { Volcanic. Should be younger } \\
\text { than UCLA-1762I: } 1800 \pm 80\end{array}$ \\
\hline UCLA-1855FF & $\begin{array}{l}\text { Babeldaob, B 18, } \\
\text { Platform I, St II. } \\
0.98 \% \text { organic C }\end{array}$ & $8150 \pm 80$ & $\begin{array}{l}\text { Volcanic. Should be close to } \\
\text { UCLA-1855BB; ca } 5000 \text { years } \\
\text { too old }\end{array}$ \\
\hline UCLA-1906 & $\begin{array}{l}\text { Raw clay sample } \\
\text { from Palau }\end{array}$ & $1890 \pm 400$ & \\
\hline
\end{tabular}

Comments: If $1890 \pm 400$ is subtracted from BP dates, UCLA-1855H, J, K, S, BB are close to the expected dates. There is greater coincidence for dates from limestone islands than from volcanic islands. All the clay is probably from the volcanic islands, but it is not certain that all these sherds were made from the same clay source.

Refs: Osborne, 1966; in press.

* Evaluation of dates and comments provided by Douglas Osborne. 
after manufacture. When fired in the $650^{\circ}$ to $898^{\circ} \mathrm{C}$ range, they can decompose, leaving $\mathrm{CaO}$. Through time, the very fine $\mathrm{CaO}$ particles reunite with $\mathrm{CO}_{2}$ from the environment, thereby introducing carbon of unknown origin, atmospheric or geologic (Shepard, 1965). Given the lack of control in firing, calcination is often incomplete. Therefore, such tempers may contain carbon from the original shell, from the prehistoric atmosphere, and from the depositional environment in unknowable proportions.

\section{Use of the vessel}

Most material that would be incorporated into the pores of ceramics during use would be foodstuffs or soot which would provide a good basis for obtaining an accurate result. However, there are exceptions. For example, post-firing treatment to render a vessel impervious may include coatings of asphaltum. Thus, care should be taken to exclude such treated vessels from the sample. Another exception pertains to the type of fuel used. In northern Arizona, coal has been documented as a prehistoric and ethnohistoric source of fuel (Brew, 1937; Hodge, 1904; Hack, 1942), and of course, in this case, soot is unreliable. UCLA-1931A may have been covered with coal soot.

\section{Depositional contamination}

Because low-fired ceramics can be especially susceptible to weathering and alteration, environments that promote such disintegration will facil-

TABLE 2

U S southwestern ceramic dates

\begin{tabular}{|c|c|c|c|}
\hline Lab no. & Sample description & Date $\mathbf{B P}$ & Associated date \\
\hline UCLA-1931A & $\begin{array}{l}\text { Moenkopi corrugated } \\
\text { ware, N Arizona }\end{array}$ & $5600 \pm 80$ & $\begin{array}{l}\text { Tree-ring dates for ware: } \\
\text { ca AD } 1100-1300^{*}\end{array}$ \\
\hline UCLA-1931B & $\begin{array}{l}\text { Homolovi corrugated } \\
\text { ware, Chevelon Ruin, N } \\
\text { Arizona }\end{array}$ & $455 \pm 90$ & $\begin{array}{l}\text { Expected date based on } \\
\text { pottery seriation, ca AD } 1400 * *\end{array}$ \\
\hline UCLA-1931F & $\begin{array}{l}\text { Corrugated ware, } \\
\text { Chevelon Ruin, } \\
\text { N Arizona }\end{array}$ & $690 \pm 110$ & $\begin{array}{l}\text { Expect ca AD 1440, based } \\
\text { on pottery seriation** }\end{array}$ \\
\hline UCLA-1931G & $\begin{array}{l}\text { Cibola corrugated } \\
\text { ware, Scribe } S \text { site, } \\
\text { New Mexico }\end{array}$ & $575 \pm 60$ & $\begin{array}{l}\text { Tree-ring dates for site } \\
\text { average AD } 1265 \text {. Occupation } \\
\text { range, AD } 1225-1280 * * *\end{array}$ \\
\hline UCLA-1948B & $\begin{array}{l}\text { Plain ware, site HS-1, } \\
\text { Hidalgo Co, } \\
\text { New Mexico }\end{array}$ & $245 \pm 80$ & $\begin{array}{l}\text { UCLA-2122A: charcoal, } \\
\text { site HS-1:490 } \pm 60 \\
\text { UCLA-2122B: charcoal, } \\
\text { site HS-1:910 } \pm 60\end{array}$ \\
\hline UCLA-1948D & $\begin{array}{l}\text { Plain ware, Pendelton } \\
\text { Ruin, Hidalgo Co, } \\
\text { New Mexico }\end{array}$ & $\begin{array}{l}>100 \% \\
\quad \text { modern }\end{array}$ & $\begin{array}{l}\text { Expect AD 1300-1400, based } \\
\text { on ceramic seriation \& } \\
\text { obsidian hydration values }\end{array}$ \\
\hline UCLA-1948F & $\begin{array}{l}\text { Plain ware, HS-15, } \\
\text { Hidalgo Co, } \\
\text { New Mexico }\end{array}$ & $\begin{array}{l}>100 \% \\
\quad \text { modern }\end{array}$ & $\begin{array}{l}\text { UCLA-2122G: charcoal, } \\
\text { HS-15: } 910 \pm 80\end{array}$ \\
\hline
\end{tabular}


itate incorporation of non-cultural carbon. In tropical environments, sherds may become impregnated with more recent organic matter (Shepard, 1965). However, this problem is not universal because none of the Amazon dates reported by Ralph (1959) and Stuckenrath (1963) were so affected. In the Palau series, sherds from volcanic contexts were extremely altered while those from the limestone islands were not (Osborne, in press). Table 1 shows that of the corrected dates, those from the limestone islands showed greater correspondence with expected ages (3 of 4 ) than did those from the volcanic islands ( 2 of 5). This suggests that in areas of volcanic activity, ceramics may be more susceptible to incorporation of dead $\mathrm{CO}_{2}$ than in other areas. Finally, in the southwestern series (table 2), the dates that show too recent ages or contamination by bomb carbon were from very shallow sites, and had long been subjected to severe mechanical alteration and surface flooding from annual rains. In general, weathered sherds are unsuitable for dating.

CONCLUSION

Because obtaining reliable ${ }^{14} \mathrm{C}$ dates on ceramic material is not always straightforward, systematic screening of potential samples is in order. Consideration of the patterns of ceramic manufacture and use for the samples involved, and of the environment in which sherds are found will substantially aid in this process.

Sherds with carbon cores are quite prevalent archaeologically, and it is not always possible to obtain a sample of the raw clay from which the original vessels were made. An alternative process is temperaturecontrolled burning. A short firing at 500 to $800^{\circ} \mathrm{C}$ should be sufficient to clear loose carbon from the pores of the ceramic. Original carbon in the clay will require longer burning at a higher temperature (Shepard, 1965; Rubin, personal communication). Collecting $\mathrm{CO}_{2}$ fractions liberated at different temperature increments should provide a means of assessing the dilution by non-cultural carbon, much as analyzing humic acid fractions on regular ${ }^{14} \mathrm{C}$ samples does.

The final problem is sample size. The percentage of organic carbon in sherd samples is usually very low. Although accurate dates can usually be obtained with about 1 percent carbon, the quantity of sherds needed (often up to several kilograms) can be prohibitive. Fortunately, developments in accelerator dating should soon reduce the importance of this limiting factor, and routine, reliable, direct dating of ceramic materials appears to be more practical than ever before.

\section{REFERENCES}

Brew, J O, 1937, The first two seasons at Awatovi: Am Antiquity, v 3, p 122-137.

Engstrand, Lars G, 1965, Stockholm natural radiocarbon measurements VI: Radiocarbon, v 5, p 82-103.

Evans, Clifford and Meggers, Betty J, 1962, Use of organic temper for carbon-14 dating in lowland South America: Am Antiquity, v 28, p 243-245.

Eyre, S R, 1968, Vegetation and soils: Chicago, Aldine Publishing Co.

Hack, John T, 1942, The changing physical environment of the Hopi Indians of Arizona: Peabody Mus Am Archaeol Ethnol, Papers, Harvard Univ, v 35, no. 1.

Hidikata, Hisakatsu, 1973, Some ceramics of Palau: Guam, Garrison and McCarter, Inc. 
Hodge, F W, 1904, Hopi pottery fired with coal: Am Anthropologist, ns, v 6, p 581-582. Lawrence, W G, 1972, Ceramic science for the potter: US, Chilton Book Co.

Martin, Paul and Plog, Fred, 1973, The archaeology of Arizona: A study of the southwest region: New York, Am Mus Nat History, Doubleday/Nat History Press.

McGregor, John C, 1965, Southwestern archaeology: Urbana, Univ Illinois Press.

Osborne, Douglas, 1966, The archaeology of the Palau Islands: Honolulu, Hawaii, Bernice P Bishop Mus Bull 230.

in press, Archaeological test excavations, Palau Islands, 1968-1969: Micronesia Supp Pub, in press.

Ralph, Elizabeth K, 1959, University of Pennsylvania radiocarbon dates III: Radiocarbon Supp, Am Jour Sci, v 1, p 45-58.

Shepard, Anna O, 1965, Ceramics for the archaeologist: Carnegie Inst Washington, Pub 609, Washington DC.

Stuckenrath, R, Jr, 1963, University of Pennsylvania radiocarbon dates VI: Radiocarbon, v 5, p 82-103.

Taylor, R E and Berger, Rainer, 1968, Radiocarbon dating of the organic portion of ceramic and wattle-and-daub house construction materials of low carbon content: Am Antiquity, v 33, p 363-366.

Taylor, R E, Swain, J L, and Berger, Rainer, 1968, New developments in the dating of ceramic artifacts: Internatl Am kong, 38th, Proc, Stuttgart-Munchen, 12-18 August 1968, v 1, p 55-60. 